\title{
Cystic Fibrosis: Enzymatic Detection of a Ciliostatic Factor
}

\author{
BAIBA K. GILLARD AND STEPHEN A. FEIG \\ Department of Pediatrics, School of Medicine, University of California, Los Angeles, California, USA \\ G. M. HARRISON AND THOMAS E. NELSON ${ }^{\prime 32}$ \\ Department of Rehabilitation, Baylor College of Medicine, Houston, Texas, USA
}

\section{Extract}

The ciliostatic cystic fibrosis (CF) factor has been investigated in order to develop an enzymatic assay for its detection. In saliva, this factor is associated with $\alpha$-amylase. Removal or addition of the factor by dialysis does not affect the $\alpha$-amylase catalytic activity of CF or control (normal) saliva. Crude preparations of the dialyzable factor from CF saliva are ciliostatic.

$\alpha$-Amylase-catalyzed starch hydrolysis from both $\mathrm{CF}$ and control saliva was found to be insensitive to hydroxyalkylamine inhibitors so this method could not be used to detect differences in $\mathrm{CF}$ and control amylase. Since another carbohydrase, mammalian debranching enzyme, is much more sensitive to inhibition, the effect of the isolated crude factor on this enzyme was determined. The mean values for percentage of inhibition of debranching enzyme activity by fractions obtained from saliva of $\mathbf{C F}$ patients, obligate heterozygotes, and control subjects are: $32 \%$ ( 27 samples), $13 \%$ ( 21 samples), and 6\% (11 samples), respectively. Fifteen of the CF values exceed the maximum $13 \%$ inhibition observed for controls. Indeed, five samples almost completely inhibited debranching enzyme. This inhibitory action provides the basis of an enzymatic assay for the detection of the ciliostatic $\mathrm{CF}$ factor.

\section{Speculation}

These studies indicate that material isolated from CF saliva which contains ciliostatic activity also inhibits mammalian debranching enzyme. This action of the factor provides an enzymatic assay for its detection to replace the current bioassays. Although the assay is a useful method of detection for research purposes, lack of chemical quantitation of the factor at present precludes its use as a means of conclusively differentiating CF, carrier, or normal individuals.

Cystic fibrosis (CF) is a genetic disorder characterized by excessive exocrine gland activity, gastrointestinal malfunction, and progressive pulmonary disability $(3,9,18)$. The basic defect is not known. However, factors have been found in the biological fluids of cystic fibrosis patients and obligate heterozygotes which may be related to the pathogenesis of the disease $(5-8,10,14,16,17,19$, 26). Factors present in serum, saliva and urine of CF homozygotes and heterozygotes interfere with the normal beat of various ciliated preparations $(5,10,19,26)$. This activity is also present in the media of cultured fibroblasts from these individuals $(6,7)$.

The ciliostatic factor from the saliva of CF patients appears to be associated with $\alpha$-amylase $(2,10,11)$. Bishop and coworkers have isolated two families of salivary $\alpha$-amylase isozymes from cystic fibrosis saliva $(2,21)$. These isozymes have disc gel electrophoretic mobilities identical with those of normal $\alpha$-amylase isozymes but, unlike the normal enzyme, exhibit ciliostatic activity. These results would indicate that a salivary ciliostatic factor is either an isozyme of normal $\alpha$-amylase, or a molecule carried by normal $\alpha$-amylase through purification (21).

This report presents the results of a determination of the relationship between $\alpha$-amylase and the ciliostatic factor, as well as the basis for an improved assay for the ciliostatic CF factor.

\section{METHODS AND MATERIALS}

Saliva was donated by CF patients treated at the Cystic Fibrosis Centers at the Texas Institute of Rehabilitation and Research and the University of California at Los Angeles School of Medicine. Obligate heterozygote saliva samples were obtained from the parents of CF patients, and control saliva samples were obtained from research associates and their children, who had no family history of CF. Small samples of whole saliva were collected with or without paraffin chewing to promote secretion. For larger samples, whole saliva was collected with the aid of Lifesaver lemon sour candy stimulation. Two candies were usually sufficient for collection of $30 \mathrm{ml}$ of whole saliva. After collection, the saliva was centrifuged at $2,000 \times g$ for $15 \mathrm{~min}$ and then filtered through glass wool. The filtrate was stored at $4^{\circ}$ for less than $24 \mathrm{hr}$ before initial assay or further use.

\section{ENZYME ASSAYS}

The $\alpha$-amylase activity of saliva was determined using a modification of Fisher and Stein's procedure (12). The rate of $\alpha$-amylase catalyzed starch hydrolysis was measured at $30^{\circ}, \mathrm{pH}$ 6.5 , in $0.05 \mathrm{M}$ maleate buffer containing $0.01 \mathrm{M} \mathrm{NaCl}, 0.05 \%$ gelatin and $0.5 \%$ Merck soluble starch. The reaction was started by addition of saliva diluted with $0.05 \mathrm{M}$ maleate buffer, pH 6.5, containing $0.01 \mathrm{M} \mathrm{NaCl}$ and $0.05 \%$ gelatin. After $15 \mathrm{~min}$, the reaction was stopped by transfer to a boiling water bath for $2 \mathrm{~min}$. The rate was determined by measuring the increase in reducing sugar concentration using a modification of the Nelson-Somogyi procedure, with glucose as a standard (25). The effect of inhibitors is expressed as the relative activity of $\alpha$-amylase in the presence and absence of the inhibitor. No maltase activity (23) could be detected under the assay conditions for starch hydrolysis. Polyamines, such as $0.05 \mathrm{M}$ spermidine, interfered with the NelsonSomogyi reagent used for determination of reducing sugar concentration. Therefore, when necessary, the starch concentration was increased to $2.5 \%$ and the $\alpha$-amylase concentration was increased by 10 -fold. The boiled reaction mixture was then diluted 10 -fold before addition of the Nelson-Somogyi alkaline copper reagent. This modification allowed use of higher concentrations of inhibitors. Mammalian debranching enzyme from rabbit muscle (amylo1,6-glucosidase/4- $\alpha$-glucanotransferase) was purified as described previously (27). Its activity was measured using glycogen phosphorylase limit dextrin as a substrate in the static assay described by Nelson, Kolb, and Larner (23). 


\section{DIALYSIS OF SALIVA}

Whole saliva collected without paraffin stimulation was used for this experiment. Dialysis tubing was presoaked to remove glycerol. The dialysis tubing used (Arthur Thomas, $5 / 8$ inch) is permeable to compounds of mol wt $<12,000$. One milliliter of cystic fibrosis saliva filtrate was transferred to a dialysis sack, and dialyzed at $4^{\circ}$, using a rocking dialyzer, against $3 \mathrm{ml}$ of either normal saliva, or $0.05 \mathrm{M}$ maleate buffer, $\mathrm{pH} 6.5$, containing $0.01 \mathrm{M} \mathrm{NaCl}$ and $0.05 \%$ gelatin. Dialysis was continued for $96 \mathrm{hr}$. The material remaining in the sack and the dialysate were assayed for ciliostatic and $\alpha$-amylase activity. Samples of saliva and buffer stored at $4^{\circ}$ for the same period, but not dialyzed were also assayed to control for any changes not related to transfer of compounds of mol wt $<12,000$.

\section{PARTIAL PURIFICATION OF CILIOSTATIC FACTOR}

Crude factor was obtained by extending Doggett and Harrison's method for the heparin treatment of saliva $(10,11)$. Whole saliva collected with lemon sour candy stimulation was used. A solution of $10 \mathrm{mg} / \mathrm{ml}$ heparin (Schwarz/Mann sodium salt 100,000 U/g) was added to the filtrate from $30 \mathrm{ml}$ whole saliva to a final concentration of $0.5 \mathrm{mg} / \mathrm{ml}$. Heparin-induced precipitate formation was complete in $48 \mathrm{hr}$ at $4^{\circ}$. The mixture was centrifuged for $15 \mathrm{~min}$ at $10,000 \times g$ and the resulting pellet was washed twice with $1 \mathrm{ml}$ of aqueous heparin solution $(0.5 \mathrm{mg} / \mathrm{ml})$. The pellet was taken up in $\mathrm{i} \mathrm{ml}$ of more concentrated heparin solution $(10 \mathrm{mg} / \mathrm{ml})$ and dialyzed against $7-15 \mathrm{ml} \mathrm{H}_{2} \mathrm{O}$ overnight. The dialysate was lyophilized and stored at $-20^{\circ}$. Up to $10 \mathrm{mg}$ lyophilized dialysate was obtained. Before assay, the lyophilized dialysate was dissolved in 1 or $2 \mathrm{ml}$ of water.

The effect of the heparin lyophilized dialysate on debranching enzyme was determined by addition of 10 to $100 \mu$ l of the dialysate solution to a total of $200 \mu 1$ in the standard limit dextrin static assay (27). Controls run simultaneously contained $10-100 \mu 1 \mathrm{H}_{2} \mathrm{O}$ in place of the dialysate solution. Ciliostatic activity of samples was measured at the Cystic Fibrosis Research Center at the Texas Institute of Rehabilitation and Research under the supervision of R. G. Doggett $(10,11)$. Protein concentration was determined using the Folin-Lowry method $(15,20)$. Absorbance was measured with a Gilford 240 or Cary 14 spectrophotometer. Amino acid analysis was performed by Dr. S. H. Bishop, on a Beckman model $120 \mathrm{~B}$ amino acid analyzer using ninhydrin for detection. $\mathrm{pH}$ values were measured at $25^{\circ}$. Deionized water was used in preparation of all solutions. 5-Amino-D-glucopyranose bisulfite (Nojirimycin bisulfate) was a gift from Dr. S. Inouye. Other chemicals used were of commercially available reagent grade.

\section{RESULTS}

Dialysis of whole CF and control saliva was done to determine the effect of partial removal or addition of constituents of mol wt $<12,000$ on the ciliostatic and the amylase activities (Fig. 1). These results indicate that at least some factor with ciliostatic activity can be transferred from CF saliva to control saliva or buffer by dialysis. The removal or addition of this factor does not affect the $\alpha$-amylase activity of either CF or control saliva.

Preparations of the dialyzable ciliostatic factor were obtained free from $\alpha$-amylase activity. Both the factor and $\alpha$-amylase are precipitated from whole saliva by addition of heparin $(10,11)$. Subsequent dialysis of the washed, resuspended precipitate separated the two activities. The dialyzable material is labile. In aqueous solution, at room temperature $\left(25^{\circ}\right)$, it loses its inhibitory activity on debranching enzyme in 6 days; at $4^{\circ}$ it loses activity in 12 days. If stored at $-20^{\circ}$ and thawed only once before assay it loses $30 \%$ of its activity in 14 days. Additional lability studies are in progress to determine the best conditions for preserving its activity.

The dialyzed factor prepared by this heparin precipitate method from CF saliva is ciliostatic. It has a broad absorption maximum

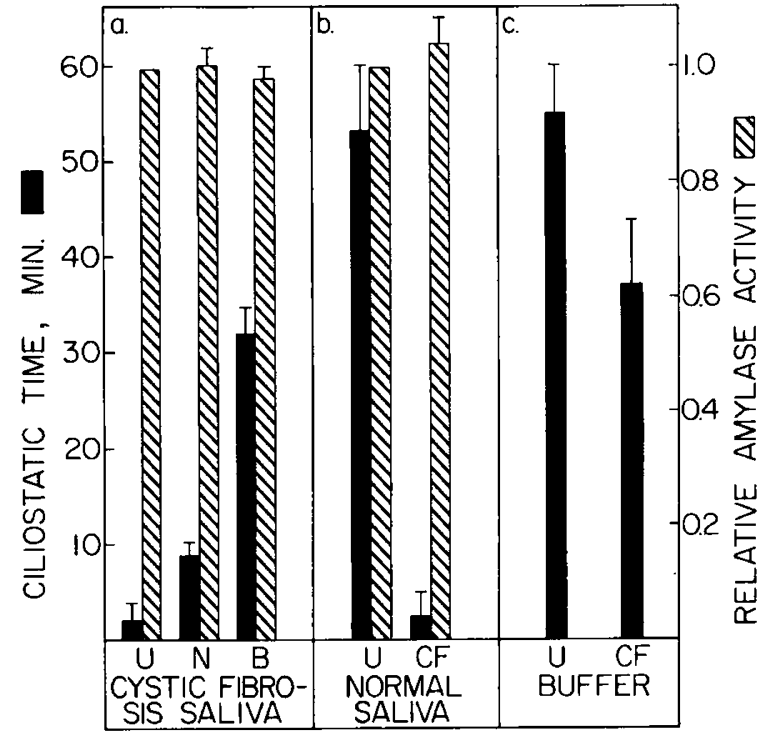

Fig. I. Effect of dialysis on ciliostatic and $\alpha$-amylase activity of saliva. Solid bars indicate ciliostatic time. Slashed bars indicate relative amylase activity. $a$ : effect on CF saliva; $U$, undialyzed activity; $N$, activity after dialysis against normal saliva; $B$, activity after dialysis against buffer, $\mathrm{pH}$ $6.5,0.05 \mathrm{M} \mathrm{Na}$-maleate, $0.05 \%$ gelatin, and $0.01 \mathrm{M} \mathrm{NaCl}$. $b$ : effect on normal saliva; $U$, undialyzed activity; $C F$, activity after dialysis against cystic fibrosis saliva. $c$ : effect on buffer; $U$, undialyzed activity; $C F$, activity after dialysis against cystic fibrosis saliva. Cilia were observed for a period of $60 \mathrm{~min}$. Samples in which cilia continue to beat for more than $60 \mathrm{~min}$ are considered to lack ciliostatic activity, (8).

at $274 \mathrm{~nm}$. Protein as measured by the Folin-Lowry assay $(15,20)$ accounts for less than one-third of its absorption and less than one-fifth of its weight. Chemical analysis of this ciliostatic fraction indicates that it contains amide or secondary amino groups, hydroxyl groups, and possibly carbonyl groups. Amino acid analysis indicates that it is only slightly ninhydrin positive. No amino acid residues could be identified before or after acid hydrolysis. The material appears to contain an amide group since after acid hydrolysis the amino acid analyzer detected an ammonia peak. This preliminary analysis of the isolated factor suggests that it may be a polyamine metabolite, such as a hydroxyalkylamine (21).

If CF amylase is a carrier for the ciliostatic factor, it might respond differently to inhibitors of amylase catalytic activity. Therefore, the effect of polyhydroxyamines on $\alpha$-amylase catalysis was tested (Table 1). The effect on rabbit muscle mammalian debranching enzyme is also shown, since hydroxyalkylamines have been found to be effective inhibitors of debranching enzyme (13, $21,22)$. The effect of these inhibitors on debranching enzyme increases with the degree of hydroxy group substitution $(13,22)$. The most potent known reversible inhibitor of debranching enzyme, 5-amino-D-glucopyranose (Nojirimycin), has very little if any effect on $\alpha$-amylase. It is evident that both cystic fibrosis and control $\alpha$-amylase are insensitive to these compounds when starch is the substrate, and inhibition effects cannot differentiate between CF and normal $\alpha$-amylase.

Since mammalian debranching enzyme (Table 1 ) is over 100 times more sensitive to hydroxyalkylamine inhibitors than is $\alpha$-amylase $(13,22,24)$, the effect of the dialyzed factor on the catalytic activity of debranching enzyme was tested (Fig. 2). The mean values for the percentage of inhibition caused by the factor isolated from saliva of CF homozygotes, heterozygotes, and controls are 32\% (27 samples), 13\% (21 samples), and 6\% (11 samples), respectively. The data does not follow a normal distribution. Twelve of the CF values fall in the range observed for normal values, $0-13 \%$, whereas the other 15 values exceed $13 \%$ inhibition. 
Table 1. Effect of hydroxyalkylamines on $\alpha$-amylase and debranching enzyme

\begin{tabular}{|c|c|c|c|}
\hline \multirow[b]{2}{*}{ Inhibitor } & \multicolumn{3}{|c|}{$\%$ Inhibition } \\
\hline & $\begin{array}{c}\text { Normal }^{1} \\
\alpha \text {-amylase }\end{array}$ & $\begin{array}{c}\text { Cystic fibrosis }{ }^{1} \\
\alpha \text {-amylase }\end{array}$ & $\begin{array}{c}\text { Debranching } \\
\text { enzyme }\end{array}$ \\
\hline \multicolumn{4}{|l|}{ Spermidine } \\
\hline \multicolumn{4}{|l|}{$\left(\mathrm{H}_{2} \mathrm{~N}\left(\mathrm{CH}_{2}\right)_{3} \mathrm{NH}\left(\mathrm{CH}_{2}\right)_{4} \mathrm{NH}_{2}\right)$} \\
\hline $100 \mathrm{mM}$ & $0 \pm 9^{2}$ & $2 \pm 9^{2}$ & \\
\hline $50 \mathrm{mM}$ & & & 0 \\
\hline \multicolumn{4}{|l|}{$\begin{array}{l}\text { Diaminohydroxyethylpropane } \\
\qquad\left(\mathrm{H}_{2} \mathrm{~N}\left(\mathrm{CH}_{2}\right)_{3} \mathrm{NH}\left(\mathrm{CH}_{2}\right)_{2} \mathrm{OH}\right)\end{array}$} \\
\hline $87 \mathrm{mM}$ & $0 \pm 7^{2}$ & $3 \pm 7^{2}$ & \\
\hline $50 \mathrm{mM}$ & & & 19 \\
\hline Bistrispropane & 0 & & $77^{3}$ \\
\hline \multicolumn{4}{|l|}{$\left(\left[\left(\mathrm{HOCH}_{2}\right)_{3} \mathrm{C}-\mathrm{NH}\right]_{2}\left(\mathrm{CH}_{2}\right)_{3}\right), 50 \mathrm{mM}$} \\
\hline Tris $\left(\left(\mathrm{HOCH}_{2}\right)_{3} \mathrm{NH}_{2}\right), 50 \mathrm{mM}$ & $0 \pm 10$ & & $68^{3}$ \\
\hline $\begin{array}{l}\text { Bistris } \\
\quad\left(\left(\mathrm{HOCH}_{2}\right)_{3} \mathrm{C}-\mathrm{N}-\left(\mathrm{CH}_{2} \mathrm{CH}_{2} \mathrm{OH}\right)_{2}\right), 4 \mathrm{mM}\end{array}$ & 0 & & $71^{3}$ \\
\hline Nojirimycin bisulfite (5-amino-D-glucopyranose bisulfite or & 5 & & $99^{3}$ \\
\hline $\begin{array}{c}\left.\mathrm{HOCH}_{2}-\mathrm{CH}-\mathrm{NH}-(\mathrm{CHOH})_{3}-\mathrm{CHOH}\right), 0.25 \mathrm{mM} \\
\mathrm{HSO}_{3}\end{array}$ & & & \\
\hline
\end{tabular}

'Saliva was used as the source of $\alpha$-amylase.

${ }^{2}$ Modified Nelson-Somogyi procedure was used.

${ }^{3}$ Calculated from $K_{1}$ values, References 13 and 22.

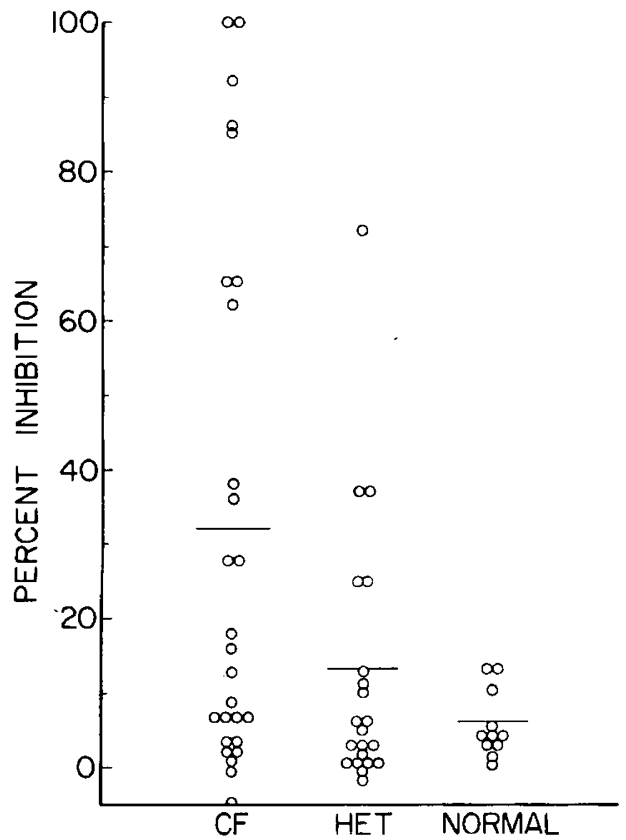

Fig. 2. Effect of heparin-precipitated dialysate on debranching enzyme. Bars indicate the mean values. $C F$ : dialysate isolated from cystic fibrosis saliva: $H E T$ : dialysate isolated from obligate heterozygote saliva; $C O N$ TROL: dialysate isolated from saliva of donors with no family history of cystic fibrosis. Values shown below $0 \%$ inhibition are within an experimental error of $\pm 5 \%$.

Indeed, five samples almost completely inhibited debranching enzyme.

\section{DISCUSSION}

Doggett and Harrison $(10,11)$ and Bishop and coworkers $(2,21)$ have reported that the $\alpha$-amylase purified from CF saliva is ciliostatic whereas that isolated from normal saliva is not. Attempts to detect differences between CF and control $\alpha$-amylase catalytic activity on starch were not successful. The $\alpha$-amylase was not affected by the inhibitors used. This insensitivity may be related to the relative size of inhibitor and substrate (24).

The dialysis studies indicate that the ciliostatic factor is a compound with mol wt $<12,000$. This value is consistent with that reported recently for the factor isolated from serum as well as that isolated from culture media derived from various cystic fibrosis cell lines (4). Like the amine inhibitors, the factor does not affect $\alpha$-amylase starch hydrolysis. Apparently $\alpha$-amylase acts as a carrier for the factor $(1,21)$. Compounds of this type, i.e., hydroxyalkylamines, bind to carbohydrases because of their structural resemblancce to glycosyl substrates $(13,21,22)$.

To facilitate further work on identification of the salivary ciliostatic factor and to determine its role in the pathophysiology of CF, it was useful to develop an enzymatic assay to replace the current ciliostatic bioassays. The ability of isolated preparations of ciliostatic factor to inhibit mammalian debranching enzyme forms the basis for such an assay. The lability of the isolated material, as well as inability to quantitate it in individual samples, probably contributes to the large range of observed inhibition. Further purification and characterization of this material should allow definition of a specific activity and development of a quantitative assay for the salivary CF factor in both crude and isolated preparations.

\section{SUMMARY}

Saliva of cystic fibrosis patients contains a dialyzable ciliostatic factor of molecular weight less than 12,000. This factor, although associated with $\alpha$-amylase, does not affect its rate of starch hydrolysis. It does, however, inhibit the activity of mammalian glycogen debranching enzyme. This action of the factor provides an enzymatic assay for its detection.

\section{REFERENCES AND NOTES}

1. Anonymous: Developments in cystic fibrosis research. Lancet, ii: 307 (1973).

2. Bishop, S. H., Reinig, M. J., and Doggett, R. G.: Chromatographic isolation of cystic fibrosis salivary isoamylases, p. 25 (Cystic Fibrosis Club Abstracts, San Francisco, 1973).

3. Bowman, B. H., Lankford, B. J., Carson, S. O., Kurosky, A., and Barnett, D. R Cystic fibrosis: The ciliary inhibitor is a small polypeptide associated with 
immunoglobulin G. Biochem. Biophys. Res. Commun., 64: 1310 (1975).

4. Bowman, B. H., Lockhart, L. H., and McCombs, M. L.: Oyster ciliary inhibition by cystic fibrosis factor. Science, 164: 325 (1969).

5. Conference Committee: Progress report on ciliary inhibitor factors, p. 2 (GAP Conference Reports, National Cystic Fibrosis Foundation, 1973).

6. Danes, B. S.: Cystic fibrosis heterozygote detection: a study on a normal population. Clin. Genet., 7: 128 (1975).

7. Danes, B. S., and Bearn, A. G.: Oyster ciliary inhibition by cystic fibrosis culture medium. J. Exp. Med., 136: 1313 (1972).

8. Danes, B. S., Beck, B., and Flensborg, E. W.: Cystic fibrosis heterozygote detection: A family study. Clin. Genet., 8: 85 (1975).

9. Di Sant'Agnese, P. A., and Talamo, R. C.: Pathogenesis and pathophysiology of cystic fibrosis of the pancreas. N. Engl. J. Med., 277: 1287, 1344, 1399 (1967).

10. Doggett, R. G., and Harrison, G. M.: Cystic fibrosis: Reversal of ciliary inhibition in serum and saliva by heparin. Tex. Rep. Biol. Med., 31: 687 (1973).

11. Doggett, R. G., and Harrison, G. M.: Cystic fibrosis: in vivo reversal of the ciliostatic character of serum and parotid secretions by heparin. Cystic fibrosis: in vitro reversal of the ciliostatic character of serum and salivary secretions by heparin. Nature New Biol., 243: 250, 251 (1973).

12. Fisher, E. H., and Stein, E. A.: $\alpha$-Amylase from human saliva. Biochem. Prep., 8: 27 (1961).

13. Gillard, B. K., and Nelson, T. E.: The use of substrate model inhibitors to study the mechanism of action of rabbit muscle amylo-1,6-glucosidase/4- $\alpha$-glucanotransferase. (In preparation.)

14. Kaiser, D., Drack, E., and Rossi, E.: Effect of cystic fibrosis sweat on sodium reabsorbtion by the normal sweat gland. Lancet, $i$ : 1003 (1970)

15. Lowry, O. H., Rosebrough, N. J., Farr, A. L., and Randall, R. J.: Protein measurement with the Folin phenol reagent. J. Biol. Chem., 193: 265 (1951)

16. Mangos, J. A., and McSherry, N. R.: Sodium transport: inhibitory factor in sweat of patients with cystic fibrosis. Science, 158: 135 (1967)

17. Mangos, J. A., McSherry, N. R., and Benke, P. J.: A sodium transport inhibitory factor in the saliva of patients with cystic fibrosis. Pediat. Res., 1: 436 (1967).

18. McCombs, M. D.: Research in cystic fibrosis. Tex. Rep. Biol. Med., 31: 615 (1973).

19. McNeely, C., and Bowman, B. H.: Cystic fibrosis: Is the ciliary inhibitor present in the urine? p. 6 (Cystic Fibrosis Club Abstracts, Denver, 1975).

20. Miller, G. L.: Protein determination for large numbers of samples. Anal. Chem. 31: 964 (1959).

21. Nelson, T. E., Gillard, B. K., and Bishop, S. H.: Salivary $\alpha$-amylase and the role of polyamine binding to carbohydrases in cystic fibrosis ciliostasis, p. 7 (Cystic Fibrosis Club Abstracts, Washington, D.C., 1974).

22. Nelson, T. E., Gillard, B. K., and White, R. C.: The mechanism of action of glycogen debranching enzyme: A catalytically bifunctional protein molecule [Abstract]. Fed. Proc., 33: 1311 (1974).

23. Nelson, T. E., Kolb, E., and Larner, J.: Purification and properties of rabbit muscle amylo-1,6-glucosidase/oligo-1,4-1,4-transferase. Biochemistry, 8: 1419 (1969).

24. Reese, E. T., Parrish, F. W., and Ettlinger, M.: Nojirimycin and D-glucono-1,5lactone as inhibitors of carbohydrases. Carbohyd. Res., 18: 381 (1971).

25. Robyt, J. F., and Whelan, W. J.: The $\alpha$-amylases. In: J. A. Radley: Starch and Its Derivatives, 4th Ed., p. 431 (Chapman and Hall, London, 1968).

26. Spock, A., Heick, H. M. C., Cress, H., and Logan, W. S.: Abnormal serum factor in patients with cystic fibrosis of the pancreas. Pediat. Res., l: 173 (1967).

27. Watts, T. E., and Nelson, T. E.: An improved purification procedure for rabbit muscle amylo-1,6-glucosidase/oligo-1,4 $\rightarrow 1,4$-glucantransferase. Anal. Biochem., 49: 479 (1972)

28. We wish to thank the staffs of the UCLA and TIRR Cystic Fibrosis Centers for assistance in collecting saliva samples. We would also like to thank Drs Richard Dooley and Alan Osher of the UCLA Cystic Fibrosis Center for continued support during the course of this investigation.

29. The Human Subject Protection Committees at UCLA, TIRR, and Baylor have approved the procedures used for collection of saliva.

30. Dr. B. K. Gillard is a Research Fellow of the National Cystic Fibrosis Research Foundation.

31. This work was supported in part by grants from the United States Public Health Service, National Institutes of Health Grants nos. AM-17524 and RR 5354.

32. Requests for reprints should be addressed to: T. E. Nelson, Ph.D., Department of Rehabilitation, Baylor College of Medicine, Houston, Tex. 77030 (USA).

33. Accepted for publication May 4, 1976.

\title{
The Rate of Cerebral Utilization of Glucose, Ketone Bodies, and Oxygen: A Comparative in Vivo Study of Infant and Adult Rats
}

\author{
G. DAHLQUIST ${ }^{(39)}$ AND B. PERSSON \\ Department of Pediatrics, Karolinska Institutet, St. Göran's Children's Hospital, Stockholm, Sweden
}

\section{Extract}

Cerebral blood flow (CBF) was measured by means of ${ }^{141} \mathrm{Ce}-$ labeled microspheres in infant (20-day-old) and adult (3-monthold) rats, anesthetised with Na-5-ethyl-5-(1-methylpropyl)2-thiobarbituric acid. Cerebral arteriovenous differences of acetoacetate, D- $\beta$-hydroxybutyrate, glucose, lactate, and oxygen and brain DNA content were determined in other groups of similarly treated infant and adult animals fed or starved for 48 or 72 hr.

The mean CBF values of $0.48 \pm 0.04$ and $0.62 \pm 0.07 \mathrm{ml} /(\mathrm{g} \times$ $\min ), \pm S E M$, in infant and adult animals, respectively, were not significantly different. CBF was unaffected by starvation.

At any given arterial concentration the cerebral arteriovenous difference of acetoacetate was significantly higher in infant than adult rats. The same was true for $D$ - $\beta$-hydroxybutyrate at arterial concentrations above $1 \mathrm{mmol} / \mathrm{liter}$. There was an approximately linear relationship between arterial concentration of acetoacetate and its cerebral arteriovenous difference in both infant and adult rats. A similar relationship was found for $D$ - $\beta$-hydroxybutyrate only in infant animals.

In the fed state, the cerebral uptake of glucose and ketone bodies (micromoles per $(\mathrm{mg} \mathrm{DNA} \times \mathrm{min})$ ) was not different in infant and adult rats. During starvation, cerebral uptake of ketone bodies expressed as micromoles per (mg DNA $\times$ min) was higher in infant than adult rats, indicating a higher rate of utilization of ketone bodies per cell in these animals. For glucose, no such difference was found in either fed or starved groups (Table 3 ). The average percentage of the total cerebral uptake of substrates (micromoles per min) accounted for by ketone bodies increased in both infant and adult rats during starvation. This percentage value was clearly 